\title{
Pathogenic mechanisms of neuronal damage in the AIDS dementia complex
}

\author{
S Swingler
}

It has become clear that infection with HIV-1 is capable of causing a progressive syndrome of neurological disease that is not strictly dependent upon the state of immunosuppression in the infected individual. ${ }^{1}$ Although the central nervous system (CNS) is often the target of opportunistic infections in the later stages of AIDS related complex (ARC) or in AIDS itself, the AIDS dementia complex (ADC), or the HIV associated cognitive motor complex as it is otherwise known, is by far the most common cause of neurological dysfunction. ${ }^{2}$ Neuropsychiatric abnormalities become most prevalent in the late stages of HIV-1 infection, and occur in $40-50 \%$ of adults and as many as $70-80 \%$ of children with clinically defined AIDS. ${ }^{3}$ Rarely, the sole indication of HIV-1 infection is the involvement of the CNS. ${ }^{45}$

Patients with the neurological syndrome associated with HIV-1 infection portray a slow, progressive degeneration of both cognitive and motor functions that does not remit. ${ }^{6}$ Frequently, it begins with mild symptoms of impaired concentration and difficulty in performing simple tasks that gradually increase in severity, leading to a major loss of intellectual capacity and complete motor disability. Finally, patients enter a nearly vegetative state that is terminal. ${ }^{7}$ The time course for progression through the disease is variable and probably dependent upon unknown host or viral factors ${ }^{5}$ but significant deterioration can occur in the course of two months to one year following the appearance of symptoms. ${ }^{6}$

\section{Neuropathological changes}

The more severe cases of ADC are characterised pathologically by prominent microgranulomatous foci of multinucleate giant cells (MGC) that are initially found in the cerebral white matter and, as the disease progresses, these abnormalities are found more frequently in the grey matter. ${ }^{38}$ The occurrence of MGC is accompanied by reactive gliosis, a term for an increase in both the size and number of astrocytes and the infiltration by cells of the monocytoid lineage, the brain derived microglial cells, and blood derived macrophages ${ }^{3}$; this condition is referred to as HIV encephalitis. Vacuolar myelopathy can also be a common pathological observation in affected brain but is more frequently found in the spinal cord. ${ }^{8}$ The earliest lesions of vacuolar myelopathy consist of intramyelin swelling causing vacuolation, while severe cases also show evidence of gross demyelination and axonal loss. These lesions are characterised by a minimal inflammatory response with macrophages only occa- sionally observed around sites of vacuolation. ${ }^{5}$ The occurrence of vacuolar myelopathy is not predicted by the presence of HIV encephalitis as the two may occur independently, or concurrently, although MGC are found more frequently in patients with severe vacuolar myelopathy. ${ }^{9}$ There is a third pathological condition identified by diffuse damage to the cerebral and cerebellar white matter that creates a general white matter pallor and has the characteristic traits of reactive gliosis, demyelination, and disseminated, perivascular infiltration by monocytic cells. ${ }^{10}$ This is referred to as progressive diffuse leucoencephalopathy as it shows evidence of an intensifying, generalised degeneration of the white matter without gross inflammation. ${ }^{8} 10$

Radiological methods of assessing CNS damage detect some gross changes in affected patients. Computed tomography shows a rise in brain atrophy and ventricular enlargement with an increased signal from the white matter as the disease progresses. ${ }^{1}$ The degree of cerebral atrophy, as judged by magnetic resonance imaging (MRI), correlates with the symptoms and progression of ADC, ${ }^{11}$ indicating that the clinical features of dementia may parallel atrophy of specific regions of the brain. ${ }^{12}$ MRI can also show abnormalities in additional regions of the CNS not clinically implicated by the symptoms and provide evidence of inflammatory changes. ${ }^{5}$ Overall, ADC affects the subcortical regions before it affects the cortical regions of the brain and, therefore, clinically it is referred to as a subcortical dementia that leads to neuronal loss in selective regions of the brain. ${ }^{12-14}$ Neurons are depleted in the orbitofrontal region of the cortex $^{15}$ and neuronal losses of $50-90 \%$ occur in the interneurons of the hippocampus. ${ }^{16}$ However, neuropathology, neuronal loss, and clinical symptoms are not absolutely correlated as has been shown by postmortem examination of the brains of some patients suffering from AIDS or ADC. ${ }^{17}$

\section{Viral invasion of the CNS and the cellular} targets of HIV-1 replication

The time at which HIV-1 gains entry into the CNS remains unclear. Aseptic meningitis is a dominant symptom of HIV-1 infection at the time of seroconversion. ${ }^{5}$ Several reports document both an early intrathecal HIV-1 specific antibody synthesis ${ }^{18}$ and an early recovery of the virus from cerebrospinal fluid (CSF), ${ }^{13} 19$ suggesting viral entry recently after infection. This may be confirmed by one tragic case of accidental infection with HIV-1, where virus 
was detected in the brain after 15 days at postmortem examination. ${ }^{17}$

By analogy to another lentivirus, Visna, free virus could cross the blood brain barrier following replication in cells of the choroid plexus $^{20}$ but a more widely held view is that HIV-1 is carried across by infected macrophages. ${ }^{514}$ This mechanism of infection is possibly facilitated by the enhanced ability of HIV-1 infected macrophages to induce adhesion molecules on the surfaces of capillary endothelial cells of the blood brain barrier, thus allowing their binding and ultimate penetration. ${ }^{14}$ Brain capillary endothelial cells can be infected in a non-cytolytic fashion by HIV-1 and may also contribute to CNS invasion by producing virus for the infection of normal leucocyte traffic. ${ }^{21}$ Once infected with HIV-1, macrophages produce high levels of the chemoattractant cytokines, macrophage inflammatory proteins $1 \alpha$ and $\beta$, which might recruit uninfected $T$ cells and monocytes to sites within the CNS and amplify the infection. ${ }^{22}$ Despite the evidence indicating early entry into the $\mathrm{CNS}, \mathrm{ADC}$ most frequently occurs late in the disease, raising the possibility that productive infection of the brain commonly occurs after a considerable time, ${ }^{13}$ or that the CNS is reseeded, probably as the levels of circulating virus in the body increase late in the disease. ${ }^{14}$ It can be speculated that the late appearance of the symptoms of ADC is due to a minor evolution of viral tropism for the CNS. The tropism of HIV-1 is determined primarily by the $\mathrm{V} 3$ region of the envelope glycoprotein, gp120, with all primary isolates of HIV-1 being able to infect both macrophage and activated $\mathrm{T}$ lymphocyte cell cultures. Two reports document CNS derived HIV-1 as possessing an altered $\mathrm{V} 3$ region in patients suffering from dementia. ${ }^{23} 24$

Following the discovery of a close association between neurological dysfunction and HIV-1 infection, many studies were undertaken to determine which elements of the CNS became infected during ADC. Shaw et al, ${ }^{25}$ studying necropsy tissue, first reported that the brain harboured considerable integrated and unintegrated HIV-1 sequences with an abundance often exceeding that seen in lymphoid tissues, such as lymph nodes and spleen. The major infected cell type in the CNS supporting viral replication was found to be the macrophage or microglial cell. ${ }^{26-28}$ The MGC found in HIV-1 encephalitis are similarly macrophage in origin ${ }^{10}$ and probably result from the fusion of infected and uninfected cells. ${ }^{29}$ Only in severe cases of HIV-1 encephalopathy are HIV-1 structural antigens found in a few neurons and astrocytes, ${ }^{29}{ }^{30}$ although significant numbers of astrocytes support limited HIV-1 replication with the production of only the non-structural Nef and Rev proteins in patients who have suffered dementia. ${ }^{31}$

The consensus, however, is that there is insufficient viral replication within macrophages and not enough detectable virus in the CNS to account for the neurological dysfunction. ${ }^{5}$ Generally, although the presence and frequency of infected cells correlates with the neuropathological findings ${ }^{29}$ and the clinical stage of ADC, the level of HIV-1 infection is still often less pronounced than the symptoms of dementia. ${ }^{13} 32$ These findings indicate that although productive brain infection, assessed by the CSF levels of the viral capsid antigen, is the closest correlate to the degree of 으 neurological damage, ${ }^{33}$ and antiretroviral therapy can delay or mitigate the symptoms of $\mathrm{ADC}^{34}$ the cause of CNS pathology and $\overrightarrow{\bar{F}}$ ultimately dementia while irrefutably linked to the presence of HIV, is only indirectly dependent upon the virus.$^{12529}$

Mechanisms of nervous system damage Since HIV-1 infection of the CNS shows no direct replication associated pathology within neuronal, astrocytic, or oligodendroglial $\overrightarrow{\vec{D}}$ cells, ${ }^{26}{ }^{29}$ what can the indirect methods of neuronal damage be? Research has demonstrated $\overline{3}$ that one (or more) viral gene product is either of directly or indirectly toxic to neuronal and iv astrocytic cells. In addition, brain macrophages and microglial cells that are virally infected o become immunologically activated to produce high levels of cytotoxic, proinflammatory cytokines and metabolites with similar toxic properties that act on neurons, oligodendrocytes, and astrocytes.

\section{VIRAL PROTEINS}

Individual viral gene products of HIV-1, particularly the envelope glycoprotein, gp120, an extracellular protein shed from virions and infected cells, have profound effects on neuronal and astrocytic cell function and cause neurotoxicity around infected macrophages producing viral antigens. ${ }^{35-42}$ The binding of free gp120 to neurons in culture causes their death via an interaction with receptors that also bind the neurotrophic factor, vasoactive intestinal peptide, that is implicated in promoting neuronal survival..$^{35}$ gp 120 , in the context of mixed neuronal-astroglial cultures, exerts potent and selective killing of hippocampal neurons ${ }^{40}$ which also become depleted in the brains of ADC patients. ${ }^{16}$ Only fragments of gp120 are required for neurotoxicity and their effects can be ameliorated by competition with an artificial $N$ peptide, peptide $\mathrm{T}^{40}$ In primary cortical cultures, the neurotoxicity of gp 120 operates in a nitric oxide dependent manner that requires $\mathrm{Ca}^{2+}$ and glutamate, the primary excitatory amino acid in the brain, ${ }^{41}$ and occurs through the activation of voltage sensitive $\mathrm{Ca}^{2+}$ channels and glutamate sensitive $\mathrm{N}$-methyl-D-aspartate channels (NMDA), which leads to an unregulated $\mathrm{Ca}^{2+}$ influx and neuronal death or dysfunction via an excitotoxic mechanism. ${ }^{41} 43$ 울 Superoxide anions that are damaging to cells are also induced by gp120 in primary cortical cultures and play a role in mediating neurotoxicity. ${ }^{41}$ Furthermore, the intracerebral $\risingdotseq$ expression of gp120 in transgenic mice produces a range of neuronal and astrocytic changes resembling those found in the human brain, the extent of which correlates with the level of gp120 expression. ${ }^{39}$

Astrocytes also possess receptors for VIP and gp120 may exert deleterious effects on their 
physiology ${ }^{36}$ or cause their death directly. ${ }^{37}$ Astrocytes primarily regulate the ionic and solute concentrations of the extracellular space, including the levels of neurotransmitters, the alteration of which will disrupt neuronal function. ${ }^{44}$ Indeed, exposure of astrocytes to gp1 20 stimulates $\mathrm{Na}^{+} / \mathrm{H}^{+}$antiport, $\mathrm{K}^{+}$conductance, and glutamate efflux. ${ }^{38}$ Astrocytic $\mathrm{Na}^{+} / \mathrm{H}^{+}$ exchange leads to intracellular alkalisation which activates the glutamate efflux and $\mathrm{K}^{+}$ channel activity in excess of the $\mathrm{Na}^{+}, \mathrm{K}^{+}-$ ATPase that reabsorbs extracellular $\mathrm{K}^{+}$. Excessive $\mathrm{K}^{+}$in the extracellular space surrounding neurons activates their voltage dependent $\mathrm{Ca}^{2+}$ channels and the increased glutamate levels activate NMDA channels. ${ }^{38}$ The resulting elevation in neuronal $\mathrm{Ca}^{2+}$ leads to depolarisation that, if prolonged, causes cellular dysfunction and death in a manner similar to the direct action of gp120 on neurons.

The viral transactivator protein, Tat, is toxic to neurons in vitro and intracerebral injection of Tat is lethal to mice. ${ }^{45}$ The protein, like gp120, is secreted from expressing cells ${ }^{46}$ and acts on neurons directly, causing their depolarisation and death. ${ }^{45}$ In the case of Tat, the activation of both NMDA and non-NMDA excitatory amino acid receptors is implicated in neuronal toxicity. ${ }^{47}$ Two other virion proteins, the envelope transmembrane protein, gp41, and the gag gene product, matrix, may be a further cause of CNS injury due to antibody cross-reactivity with surface epitopes on astrocytes. $^{48-50}$ The immunodominant epitope of gp41 is shared by astrocytes and astrocyte reactive antibodies are present in some patients with neurological complications. ${ }^{49}$

THE HIV-1 INFECTED, ACTIVATED MACROPHAGE The productive infection of macrophages with HIV-1 primes the cell for immunological activation probably though an IFN $\gamma$-like pathway even though there are relatively low numbers of IFN $\gamma$ secreting lymphocytes within the CNS. ${ }^{14}$ The viral matrix protein has structural similarities with IFN $\gamma^{51}$ and HIV may have developed mechanisms to mimic the action of the cytokine. Subsequent immunological activation of the primed, infected macrophage then occurs via direct interactions with astrocytes $^{5253}$ (facilitated by the ability of gp120 to induce adhesion molecule expression on the surface of the astrocyte), ${ }^{54}$ exposure to endogenous brain chemicals, such as endorphins, ${ }^{55}$ or interaction with opportunistic infections already present in the CNS. ${ }^{14}$ Once activated, HIV-1 infected macrophages produce significant amounts of the cytokines, TNF $\alpha$ and IL-1 $\beta$, and the bioactive metabolites, eicosanoids, quinolinic acid, platelet activating factor (PAF), and nitric oxide, which are directly or indirectly neurotoxic. ${ }^{14}{ }^{53} 56-62$ The levels of most of these potential neurotoxins (TNF $\alpha$, IL-1 $\beta$, quinolinic acid, PAF, eicosanoids and the inducible form of nitric oxide synthetase) are known to be elevated in the CSF or brain tissue of patients with neurological disease. ${ }^{14566364}$

Of the cytokines, TNF $\alpha$ mediates neuronal damage and dysfunction at several levels. It is known to upregulate HIV-1 replication and may act on infected macrophages in an autocrine manner ${ }^{65}$ to increase the production of neurotoxic viral proteins, while at the same time it is cytotoxic to both oligodendrocytes and neurons by an apoptotic mechanism. ${ }^{60} 61$ At subcytotoxic doses, but in the presence of a glutamate receptor agonist, it exerts neurotoxicity by activation of the neuronal $\alpha$-amino-3hydroxy-5-methylisoxazole-4-proprionic acid (AMPA) subtype of glutamate receptor channels, ${ }^{53}$ and it has been noted that there is a loss of AMPA receptor protein in the brains of AIDS patients. ${ }^{66}$ TNF $\alpha$ stimulates $\mathrm{Na}^{+} / \mathrm{H}^{+}$ exchange in the membranes of astrocytes, in a manner similar to gp120, with identical neurotoxic potential ${ }^{57}$ but, furthermore, it inhibits astrocytic glutamate reuptake, compounding the processes leading to unregulated $\mathrm{Ca}^{2+}$ influx and neuronal damage via voltage dependent $\mathrm{Ca}^{2+}$ channels and NMDA operated receptor channels. ${ }^{62}$ IL- $1 \beta$ can also contribute to the degeneration of oligodendrocytes in conjunction with $\mathrm{TNF} \alpha^{67}$ and alone it promotes $\mathrm{Na}^{+} / \mathrm{H}^{+}$exchange in astrocytes. ${ }^{57}$ In addition, IL- $1 \beta$ is the cause of astrocyte proliferation. ${ }^{68}$ Quinolinic acid exerts direct neuronal toxicity via stimulation of the NMDA receptor channels and the subsequent increase in intracellular $\mathrm{Ca}^{2+} .{ }^{69}$ Nitric oxide similarly produces neurotoxicity via NMDA receptors, although in itself it does not appear to do so directly, it first combines with the superoxide anion to form a toxic intermediate. ${ }^{14}$ PAF is a lipid mediator that is also a potent neurotoxin which again acts via NMDA receptors ${ }^{58}$ causing glutamate mediated excitotoxicity and inducing a rise in neuronal intracellular $\mathrm{Ca}^{2+} \cdot{ }^{70}$ PAF could further potentiate neurotoxicity indirectly as it is a potent inducer of TNF $\alpha$ and IL-1 $\beta$ production from macrophages. ${ }^{71}$ Of the eicosanoids, prostaglandins E2, F2 $\alpha$, and thromboxane $\mathrm{B} 2$ are elevated in the CNS of demented patients and are potent neuromodulators that promote cell injury. ${ }^{63}$ Finally, arachidonic acid can also inhibit astrocyte reuptake of glutamate, promoting the potential for neuronal excitotoxicity via NMDA receptors. $^{72}$

\section{Conclusions}

Current research has identified the infected macrophage or microglial cell as the initiator of neuronal dysfunction and death in ADC through the production of viral gene products, notably gp 120, and diffusable, cellular neurotoxins, the synthesis of which becomes enhanced after interaction with resident astrocytic cells. Astrocytes serve a dual role in ADC initially preventing neuronal damage by maintaining the extracellular microenvironment but, increasingly, as the numbers of infected macrophages rises amplifying the excitotoxic mechanism of neuron damage. The majority of viral or macrophage produced neurotoxins act directly or indirectly via voltage dependent $\mathrm{Ca}^{2+}$ channels and NMDA receptor operated channels, a mechanism that is not unique to ADC, but also is believed to occur in other neurodegenerative diseases, such as Hunting- 
ton's disease, Parkinson's disease and amyotrophic lateral sclerosis. ${ }^{43}$ Clinically tolerated antagonists of these pathways, such as memantine, are undergoing trials as potential therapies for ADC. ${ }^{17}{ }^{43}$ In addition, drugs that limit the synthesis of specific macrophage derived inflammatory products, PAF and eicasonoids, are also being developed ${ }^{14}$ in the hope that they will ameliorate the symptoms of ADC more effectively than antiretroviral drugs alone.

I am grateful to Dr Alan Morris for helpful discussions and critical reading of a draft of this paper.

1 Price RW, Sidtis J, Rosenblum M. The AIDS dementia complex: some current questions. Ann Neurol 1988;23:27complon

2 Elder GA, Sever JL. AIDS and neurological disorders: an overview. Ann Neurol 1988;23:4-6.

3 Petito CK. Review of central nervous system pathology in human immunodeficiency virus infection. Ann Neurol 1988;23:54-7.

4 Navia BA, Price RW. The acquired immunodeficiency syndrome dementia complex as the presenting or sole manifestation of human immunodeficiency virus infection. Arch Neurol 1987;44:65-9.

5 Wiley CA, Nelson JA. Human immunodeficiency virus infection of the nervous system. Curr Top Microbiol Immunol 1990;160: 157-69.

6 Moller AA, Gasser T, Jäger H, Hedl A. Clinical course of subacute HIV-1 encephalitis. $\mathcal{f}$ Neuroimmunol 1988;20 145-7.

7 Price RW, Brew BJ. The AIDS dementia complex. $\mathcal{f}$ Infect Dis 1988;158:1079-83

8 Rostad SW, Sumi SM, Shaw C, Olson K, McDougall JK. Human immunodeficiency virus (HIV) infection in brains
with AIDS-related leukoencephalopathy. AIDS Res Hum with AIDS-related leukoence

9 Petito CK, Cho E, Lemann W, Navia BA, Price RW. Neuropathology of acquired immunodeficiency syndrome (AIDS): an autopsy review. $\mathcal{f}$ Neuropathol Exp Neurol 1986 45:635-46.

10 Budka $\mathrm{H}$. Human immunodeficiency virus (HIV)-induced disease of the central nervous system: pathology and implications for pathogenesis. Acta Neuropathologica 1989;77, 225-36.

11 Levin HS, Williams DH, Borucki MJ, Hillman GR, Williams JB, Guinto FC, et al. Magnetic resonance imaging and neuropsychological findings in human immunodeficiency virus infection. F Acq Imm Def Synd 1990;3:757-62.

2 Aylward EH, Henderer JD, McArthur JC, Brettschneider PD, Harris GJ, Barta PE, et al. Reduced basal ganglia volume in HIV-1-associated dementia: results from quantitative neuroimaging. Neurology 1993;43:2099-104.

13 Brew BJ, Rosenblum M, Cronin K, Price RW. AIDS dementia complex and HIV-1 brain infection: clinicalvirological correlations. Ann Neurol 1995;38:563-70.

14 Nottet HS, Gendelman HE. Unravelling the neuroimmune mechanisms for the HIV-1-associated cognitive/motor complex. Immunol Today 1995;16:441-8.

15 Ketzler S, Weiss S, Haung H, Budka H. Loss of neurons in the frontal cortex in AIDS brains. Acta Neuropathologica 1990;80:92-4

16 Masliah E, Ge N, Achim CL, Hansen LA, Wiley CA. Selective neuronal vulnerability in HIV encephalitis. $\mathcal{f}$ Neuropathol Exp Neurol 1992;51:585-93.

17 McGuire D, Greene WC. Neurological damage in HIV infection. In: Lever AML, ed. The molecular biology of HIV AIDS. Chichester: John Wiley and Sons, 1995:127-42.

18 Gallo P, De Rossi A, Amadori A, Tavolato B, ChiecoBianchi L. Central nervous system involvement in HIV infection. AIDS Res Hum Retroviruses 1988;4:211-21.

19 Brew BJ, Rosenblum M, Price RW. AIDS dementia complex and primary HIV brain infection. $\mathcal{F}$ Neuroimmunol $1988 ; 20$ : 133-40

20 Wigdahl B. Role of HIV in human nervous system dysfunction. AIDS Res Hum Retroviruses 1989;5:369-74.

21 Moses AV, Nelson JA. HIV infection of human brain capillary endothelial cells-implications for AIDS dementia. Adv Neuroimmunol 1994;4:239-47.

22 Schmidtmayerova H, Nottet HS, Nuovo G, Raabe T, Flanagan CR, Dubrovsky L, et al. Human immunodeficiency virus type 1 infection alters chemokine beta peptide expression in human monocytes: implications for recruitment of leukocytes into brain and lymph nodes. Proc Nat Acad Sci USA 1996;93:700-4.

23 Power C, McArthur JC, Johnson RT, Griffin DE, Glass JD, Perryman S, et al. Demented and nondemented patients with AIDS differ in brain-derived human immunodefiwiency virus type 1 envelope sequences. F Virol 1994;68: ciency viru

24 Kuiken CL, Goudsmit J, Weiller GF, Armstrong JS, Hartman S, Portegies P, et al. Differences in human immunodeficiency virus type 1 V 3 sequences from patients with and without AIDS dementia complex. F Gen Virol 1995;76: 175-80

25 Shaw GM, Harper GM, Hahn BH, Epstein LG, Gajdusek DC, Price RW, et al. HTLV-III infection in brains of children and adults with AIDS encephalopathy. Science 1985;227:177-82.

26 Koenig S, Gendelman HE, Orenstein JM, Dal Canto MC Pezeshkpour GH, Yungbluth M, et al. Detection of AIDS virus in macrophages in brain tissue from AIDS patients with encephalopathy. Science 1986;233:1089-93.

27 Meyenhofer M, Epstein LG, Cho E, Sharer LR. Ultrastructural morphology and intracellular production of human immunodeficiency virus (HIV) in brain. $\mathcal{F}$ Neuropathol Exp Neurol 1987;46:474-84

28 Vazeux R, Brousse N, Jarry A, Henin D, Marche C, Vedrenne C, et al. AIDS subacute encephalitis: identification of HIV-infected cells. Am f Pathol 1987;126:403-10.

29 Wiley CA, Schrier RD, Nelson, JA, Lampert PW, Oldstone MBA. Cellular localisation of human immunodeficiency virus infection within brains of acquired immune defivirus infection within brains of acquired immune deficiency syndrome

30 Stoler MH, Eskin TA, Benn S, Angerer RC, Angerer LM. Human T-cell lymphotropic virus type III infection of the central nervous system: a preliminary in situ analysis. $\mathcal{f} \mathrm{Am}$ Med Assoc 1986;256:2360-4.

31 Ranki A, Nyberg M, Ovod V, Haltia M, Elovaara I, Raininko $\mathrm{R}$, et al. Abundant expression of HIV Nef and Rev proteins in brain astrocytes in vivo is associated with dementia. in brain astrocytes in $1995 ; 9: 1001-8$.

32 Neun-Jacob E, Arendt G, Wendtland B, Jacob B, Schneeweis $M$, Wechsler W. Frequency and topographical distribution of CD68-positive macrophages and HIV-1 core proteins in HIV-associated brain lesions. Clin Neuropathol 1993;12:315-24.

33 Royal W, Selnes OA, Concha M, Nance-Sproson TE, McArthur JC. Cerebrospinal fluid human immunodeficiency virus type 1 (HIV-1) p24 antigen levels in HIV-1-related dementia. Ann Neurol 1994;36:32-9.

34 Gray F, Belec L, Keohane C, De Truchis P, Clair B, Durigon $\mathrm{M}$, et al. Zidovudine therapy and HIV encephalitis: a 10 year neuropathological survey. AIDS 1994;8:489-93.

35 Brenneman DE, Westbrook GL, Fitzgerald SP, Ennist DL, Elkins KL, Ruff MR, et al. Neuronal cell killing by the envelope protein of HIV and its prevention by vasoactive intestinal peptide. Nature 1988;335:639-42.

36 Wilkin GP, Cholewinski A. Peptide receptors on astrocytes. In: Kimelberg HK, ed. Glial cell receptors. New York: Raven Press, 1988:223-41.

37 Pulliam L, West D, Haigwood N, Swanson RA. HIV-1 envelope gp 120 alters astrocytes in human brain cultures. AIDS Res Hum Retroviruses 1993;9:439-44.

38 Benos DJ, Hahn BH, Bubien JK, Ghosh SK, Mashburn NA, Chaikin MA, et al. Envelope glycoprotein gp120 of human immunodeficiency virus type 1 alters ion transport in astrocytes: implications for AIDS dementia complex. Proc Natl Acad Sci USA 1994;91:494-8.

39 Toggas SM, Masliah E, Rockenstein EM, Rall GF, Abraham CR, Mucke L. Central nervous system damage produced by expression of the HIV-1 coat protein gp120 in by expression of the HIV-1 coat prote
transgenic mice. Nature 1994;367:188-93.

40 Brenneman DE, McCune SK, Mervis RF, Hill JM. gp 120 as an etiologic agent for NeuroAIDS: neurotoxicity and model systems. Adv Neuroimmunol 1994;4:157-65.

41 Dawson TM, Dawson VL. gp120 neurotoxicity in primary cortical cultures. Adv Neuroimmunol 1994;4:167-73.

42 Bubien JK, Benveniste EN, Benos DJ. HIV-1 gp120 activates large-conductance apamin-sensitive potassium activates large-conductance apamin-sensitive potassium

43 Lipton SA. Neuronal injury associated with HIV-1 and potential treatment with calcium-channel and NMDA antagonists. Dev Neurosci 1994;16:145-51.

44 Barres BA. New roles for glia. $\mathcal{f}$ Neurosci 1991;11:3685-94. 45 Sabatier J, Vives E, Mabrouk K, Benjouad A, Rochat H, Duval A, et al. Evidence for neurotoxic activity of Tat from human immunodeficiency virus type 1. F Virol 1991;65: 961-7.

46 Helland DE, Repke H, Caputo A, Haseltine WA. The exogenous transactivation activity of HIV-1 Tat. In: Haseltine WA, Wong-Staal F, eds. Harvard AIDS Institute series on gene regulation of human retroviruses. Vol 1. New York: Raven Press, 1991:301-10.

47 Magnuson DS, Knudsen BE, Geiger JD, Brownstone RM, Nath A. Human immunodeficiency virus type 1 Tat activates non- $N$-methyl-D-aspartate excitatory amino acid receptors and causes neurotoxicity. Ann Neurol 1995;37: 373-80.

48 Parravicini CL, Klatzmann DL, Jaffray P, Costanzi G, Gluckman JC. Monoclonal antibody to the human immunodeficiency virus p18 protein cross-reacts with normal human tissues. AIDS 1988;2:171-7.

49 Yamada $M$, Zurbriggen A, Oldstone MBA, Fujinami RS Common immunological determinant between human immunodeficiency virus type $1 \mathrm{gp} 41$ and astrocytes. 7 Virol 1991;65:1370-6.

50 Spehar T, Strand M. Cross-reactivity of anti-human immunodeficiency virus type 1 gp41 antibodies with human astrocytes and astrocytoma cell lines. F Virol 1994;68: 6262-9.

51 Matthews S, Barlow P, Boyd J, Barton G, Russell R, Mills H, et al. Structural similarity between p17 matrix protein of et al. Structural similarity between p17 matrix protein

52 Genis P, Jett M, Bernton EW, Gelbard HA, Dzenko K, Keane R, et al. Cytokines and arachidonic acid metabolites produced during HIV-infected macrophage-astroglial interactions: implications for the neuropathogenesis of HIV disease. F Exp Med 1992;176:1703-18.

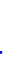


53 Gelbard HA, Dzenko KA, DiLoreto D, del Cerro C, del Cerro M, Epstein LG. Neurotoxic effects of tumour necrosis factor alpha in primary human neuronal cultures are mediated by activation of glutamate AMPA receptor subtype: implications for AIDS neuropathogenesis. Dev Neurosci 1993;15:417-22.

54 Shrikant P, Benos DJ, Tang LP, Benveniste EN. HIV glycoprotein 120 enhances intercellular adhesion molecule-1 gene expression in glial cells: involvement of Janus kinase/signal transducer and activator of transcription and protein kinase C signalling pathways. F Immunol 1996;156: protein kinas $1307-14$.

55 Sundar KS, Kamaraju LS, Dingfelder J, McMahon J, Gollapudi S, Wilson WH, et al. Beta-endorphin enhances the replication of neurotropic human immunodeficiency virus in foetal perivascular microglia. I Neuroimmunol 1995;61:97-104

56 Achim CL, Heyes MP, Wiley CA. Quantitation of human immunodeficiency virus, immune activation factors and quinolinic acid in AIDS brains. f Clin Invest 1993;91: 2769-75.

57 Benos DJ, McPherson S, Hahn B, Chaikin MA, Benveniste EN. Cytokines and HIV envelope glycoprotein gp 120 EN. Cytokines and $\mathrm{HIV}$ envelope glycoprotein gp 120
stimulate $\mathrm{Na}^{+} / \mathrm{H}^{+}$exchange in astrocytes. F Biol Chem stimulate $\mathrm{Na}^{+} / \mathrm{H}^{+}$

58 Gelbard HA, Nottet HSLM, Swindells S, Jett M, Dzenko KA, Genis P, et al. Platelet-activating factor: a candidate human immunodeficiency virus type 1 -induced neurotoxin. 7 Virol 1994;68:4628-35.

59 Lipton SA, Yeh M, Drever EB. Update on current models of HIV-related neuronal injury: platelet-activating factor, arachidonic acid and nitric oxide. Adv Neuroimmunol 1994;4: $181-8$.

60 Talley AK, Dewhurst S, Perry SW, Dollard SC, Gummuluru $\mathrm{S}$, Fine $\mathrm{SM}$, et al. Tumour necrosis factor alphainduced apoptosis in human neuronal cells: protection by the antioxidant $\mathrm{N}$ acetylcysteine and the genes bcl-2 and crmA. Mol Cell Biol 1995;15:2359-66.

61 Wilt SG, Milward E, Zhou JM, Nagasato K, Patton H, Rusten $\mathrm{R}$, et al. In vitro evidence for a dual role of tumour necrosis factor-alpha in human immunodeficiency virus type 1 encephalopathy. Ann Neurol 1995;37:381-94.

62 Fine SM, Angel RA, Perry SW, Epstein LG, Rothstein ID, Fine SM, Angel RA, Perry SW, Epstein LG, Rothstein JD,
Dewhurst S, et al. Tumour necrosis factor alpha inhibits glutamate uptake by primary human astrocytes: implications for pathogenesis of HIV-1 dementia. 7 Biol Chem 1996;271:15303-6.

63 Griffin DE, Wesselingh SL, McArthur JC. Elevated central nervous system prostaglandins in human immunodeficiency-associated dementia. Ann Neurol 1994;35:5927.

64 Sei S, Saito K, Stewart SK, Crowley JS, Brouwers P, Kleiner $\mathrm{DE}$, et al. Increased human immunodeficiency virus (HIV) type 1 DNA content and quinolinic acid concentration in brain tissues from patients with HIV encephalopathy. $7 \mathrm{In}$ fect Dis 1995;172:638-47.

65 Rosenberg ZF, Fauci AS. Immunopathogenic mechanisms of HIV infection: cytokine induction of HIV expression. Immunol Today 1990;11:176-80.

66 Everall IP, Hudson L, Al-Sarraj S, Honavar M, Lantos P, Kerwin R. Decreased expression of AMPA receptor messenger RNA and protein in AIDS: a model for HIV-associated neurotoxicity. Nature Med 1995;1:1174-8.

67 Hofman FM. Cytokines in central nervous system disease. In: Goetzl EJ, Spector NH, eds. Neuroimmume networks: physiology and disease. New York: Alan R Liss Inc, 1989:65-71.

68 Giulian D, Lachman LB. Interleukin-1 stimulation of astroglial proliferation after brain injury. Science 1985;228:497 9 .

69 Brew BJ. The clinical spectrum and pathogenesis of HIV encephalopathy, myelopathy and peripheral neuropathy. Curr Opin Neurol 1994;7:209-16.

70 Bito H, Nakamura M, Honda Z, Isumi T, Iwatsubo T, Seyama T, et al. Platelet-activating factor (PAF) receptor in rat brain: PAF mobilises intracellular $\mathrm{Ca}^{2+}$ in hippocampa neurons. Neuron 1992;9:285-94.

71 Hogan MM, Vogen SN Production of TNF by rIFNgamma-primed $\mathrm{CC} 3 \mathrm{HH} / \mathrm{HeJ}$ (Lps ${ }^{\mathrm{d}}$ ) macrophages requires the presence of lipid-A-associated proteins f Immunol 1988;141:4196-9.

72 Volterra A, Trotti D, Cassutti P, Tromba C, Salvaggio A Melcangi RC, et al. High sensitivity of glutamate uptake to extracellular free arachidonic acid levels in rat cortical synaptosomes and astrocytes. F Neurochem 1992;59:600-6. 